\title{
A Review on fuzzy multi-criteria decision making land clearing for oil palm plantation
}

\author{
Hamdani $^{\mathrm{a}, 1}{ }^{*}$, Retantyo Wardoyo ${ }^{\mathrm{b}, 2}$ \\ ${ }^{a}$ Departement of Computer Science, Universitas Mulawarman, Indonesia \\ ${ }^{b}$ Departement of Computer Science and Electrical, Universitas Gadjah Mada, Indonesia \\ ${ }^{1}$ hamdani@unmul.ac.id*; ${ }^{2}$ rw@ugm.ac.id
}

\begin{abstract}
ARTICLE INFO
ABSTRACT

Article history:

Received May 27, 2015

Revised June 03, 2015

Accepted July 30, 2015

Keywords:

Fuzzy Multi-Criteria

Decision Making,

FAHP,

Land Clearing,

Plantation.

Our review paper research categorize the methods in the method of Fuzzy Multi-Criteria Decision Making (FMCDM) to find the method is widely used in the case of land clearing for plantation. Model FMCDM is used to assess the parameter in multi-criteria-based decision making. The dominant percentage of the result was obtained using Fuzzy Analytic Hierarchy Process (FAHP) method. While the application of other methods for the same problem are Fuzzy Ordered Weighted Averaging (FOWA), Fuzzy Elimination Et Choix Traduisant la Realite or Elimination and Choice Translating Reality (FELECTRE), Fuzzy Technique for Order Preference by Similarity to Ideal Solution (FTOPSIS), Fuzzy, Artificial Neural Networks (FANNs) has less. Some the research result also implemented hybrid in FMCDM Method to give some weight in the assessment of decision making. There was also a paper which integrates FMCDM to the GIS method on the land clearing. Therefore, it is concluded that the issue on the land clearing can be done through collaboration of several models of FMCDM, so that it can be developed by involving the decision model using multi-stakeholder model.
\end{abstract}

Copyright (c) 2015 International Journal of Advances in Intelligent Informatics. All rights reserved.

\section{Introduction}

Our research categorize and analyze the model of decision making to support the decision making process in the land clearing for plantation using Fuzzy Multi-Criteria Decision Making method (FMCDM). FMCDM method can be used in decision making process on the issues which are uncertain and complex [1]-[4]. The issue is expected to be able to help the multi-stakeholders to make an appropriate decision in land clearing [5]-[11]. In this matter, the FMCDM method is used for the issue of land clearing for plantation or farming [12]-[15]. The land clearing for plantation is meant for big scale such as palm plantation. The issue on the plantation plays an important role for the sustainability of the people. Therefore, the maintenance of big-scale plantation needs a sustainable development of natural resources [16]-[20].

Indonesia and Malaysia have been known as the world's biggest producers of palm oil [16], [20]. Currently the palm plantation in Indonesia is estimated to reach 20.6 million hectare [21]. The result of census data in 2012 of the United States Department of Agriculture (USDA) shows that Indonesia is the world's biggest producer of palm oil with $50 \%$ of the world's palm oil production comes from Indonesia [22]. Therefore, Indonesia has the potential to have the resource of the very important palm oil plantation to support the development of people's economy.

More land clearing for plantation needs a proper maintenance of the environment so that the natural resources are protected within the area of plantation and the forest [23]. Hence, evaluation and accurate planning is needed for land clearing for plantation so that it can protect the ecosystem within [24]. The objective of the research is to measure how much the FMCDM method in making the decision for land clearing using Fuzzy Analytic Hierarchy Process (FAHP), Fuzzy Ordered Weighted Averaging (FOWA), Fuzzy ELimination Et Choix Traduisant la Réalité or Elimination and Choice Translating Reality (FELECTRE), Fuzzy Technique for Order Preference by Similarity 
to Ideal Solution (FTOPSIS), and Fuzzy Artificial Neural Networks (FANNs) to help finishing the land clearing issue.

\section{Methode of Fuzzy Multi-Criteria Decision Making}

The basic theory of Fuzzy Multi-Criteria Decision Making (FMCDM) is the alternative result known and determined previously for decision making based on the data of criteria [1], [3], [4], [25]. This method can also be found in Yager model, which is the standard form of FMCDM [26]. FMCDM Method uses such basic theory applied in fuzzy method for decision making, which is called Fuzzy Logic (FL). The first FL was introduced by Professor Lotfi A Zadeh in the University of California, Berkeley, United States. This model is used to represent the issue of uncertainty, so that the issues of decision making using multi-criteria can be applied in FL Method. The involvement of FL in developing Multi-Criteria Decision Making (MCDM) model is meant to improve the decision making on the bias matters. In FMCDM method, amongst the land clearing method is the method of FAHP and AHP. The theory is used to measure the comparison of paired criteria. Basically, AHP lower the measurement scale of two comparison decrees and continuously [27]. FAHP is designed to capture the rational perception of the people who are closely related to particular issues through the procedures designed to reach the preferred scale among various uncertain alternative decisions. FAHP is a method which strongly uses some criteria to make some decision [28]. The method is also used in the decision of multi-criteria, planning, management, allocation of resources and the determination of the priority in conflicted situation [29] even the completion of decision making individually or in group [30]. Some research result can be implemented in the issue of criteria comparison for land clearing [5]-[15].

Fuzzy Ordered Weighted Averaging (FOWA) method was first introduced by Yager. Aggregating opinions of experts that will produce group decision, here FOWA plays a very important role in helping Group Decision Making (GDM). Operator FOWA must be commutative, idempotent, sustainable, neutral, compensative, and stable in liner transformation. FOWA operators sequence the arguments to be delivered based on the value of the response given [10], [26], [31], [32]. On the method of Fuzzy Technique for Order Preference by Similarity to Ideal Solution (FTOPSIS), it follows the steps to make matrix of normalized, weight-normalized, positive and negative ideal solution decision, the distance between the alternative value with the positive and negative matrix, and determine the preference value for each alternative decision [33], [34]. So that this method can also be implemented on its decision making on the land clearing [9], [35].

Fuzzy ELimination Et Choix Traduisant la Réalité or Elimination and Choice Translating Reality (FELECTRE) method is a concept of paired comparative ranking between the alternative appropriateness in a certain criteria. The presentation of the FELECTRE method is to implement the formation of concord index and discordance index for each alternative through the estimation towards the ranking relation [36]-[39]. Some implementations of the result have been used for decision making over land clearing [5], [10], [15] and combine them to some other methods. While in the method of Fuzzy Artificial Neural Networks (FANNs) is a model of nerve tissue developed to practice the model which based on the bias topology. The model is used to write historical data and renew the information within the database for alternative from time to time for the future decision making. Model FANN can be used to learn the relationship between the criteria and alternative as well as the alternative ranking alternative [40]-[42]. FANN method is also used in the implementation for decision making over land clearing [12], [13].

\section{Plantation}

Plantation and farming are two related things. Since both are part of planting. Farming is developing and the utilization of natural resources especially the productive plan which produce and can be used as in human's lives. While in a narrow sense, farming is a process of planting in a land prepared in a small scale, [43]. On the other hand, plantation is a farming system with bigger orientation which of course later will be traded from a result of farming commodity. The plantation land is a land for farming in a wide field, often times it is located in tropical or subtropical area, which is used as the producers of farming commodity in big scale and it can be marketed going the distance. Mostly plantation is oriented to the hard plants or plants which lasts long which is 
cultivated and uses a good management pattern. For example: rubber, coconut, palm, sugarcane, coffee, tea and many other plantation [44].

\section{A. Land Clearing}

The conversion of the forest into farming land or the like might disturb many species within which will be changed along with the land clearing, such as forest conversion into farming land pertanian [45], [46]. There are some land clearing, such as land clearing for farming [12], [14], [15], [47], [48], settlement [49], [50], industry [51], final disposal site [52] and other. The objective of the land clearing is to convert unproductive land into productive land [20], [21], [23], [46], [48].

\section{B. The effects of plantation land clearing}

Effects of too much land clearing for plantation each year might decrease the water content and change the biophysical characteristic of turf field, so that degradation occurs that causes $\mathrm{pH}$ (potential of Hydrogen) of water and the level of ash are increasing [21]. The effect of overly land clearing can also cause soil erosion for there is no more roots to hold on [53]. Therefore, what needs to be concerned in land clearing is the maintenance of the land before and after the plant, so that the environmental effects after the land clearing might be minimized [20], [45]. Some issues caused by forest damage after the land clearing is fragmented forest, smaller forest area, soil erosion and the losing of variety of plants and the ecosystem within [45], [53].

\section{Result and Analysis}

\section{A. Discussion result}

The The research done [5] presented FAHP approach to determine the weight of the subjective assessment over the technical issue on green industry. The technique is applied to the green area issue and its effects to the surrounding area. The parameter used for decision making such as economic condition, technical feasibility, and the environmental rules. The purpose of the research used FMCDM method involving stakeholders, so that the model can be said as group decision making. The model used hybrid to some other method such as FELECTRE and Fuzzy Simple Additive Weighting (FSAW). The research also used Fuzzy Non-additive for effective and accurate evaluation, especially when there is a dependent criteria. There are some weaknesses on this research as it did not show the visualization result of the location or the green area on the environmental effect that will be selected. Therefore, it needs to develop model hybrid of FMCDM that can be collaborated within GIS method.

While this research [6] used hybrid method to make decision of planning of land utilization, so that it could identify the exact location for certain type of soil. This study is aimed at decision maker was used to formulate the land utilization resulting different alternative locations. The research used some FMCDM method such as FAHP, AHP and Geographic Information System (GIS) method to visualize the location. FAHP method was used to analyze the parameter and the criteria to result on the output with GIS visualization to recommend the land utilization. The research also aimed to boost the productivity of the land using Erosion Tolerance Index (ETI) method which aimed to minimize the risk of erosion and Curve Number $(\mathrm{CN})$ method to maximize the setting of water debit. The weakness of the research is that it did not involve the model of decision involving multistakeholder to plan the land utilization, so that the decision model that can accommodate the interest of the stakeholders in group decision making is needed.

Research result of [7] also used combination of FMCDM for land clearing. However, the combination of this model is used to determine the location of urban land using GIS visualization to be analyzed using FMCDM method. The study aims to measures the environmental parameter, biophysical, ecological, social and economic parameter as well. FAHP method is used to analyze each sub-criteria for decision making over the land suitability. The weakness of the research is because the research also did not involve stakeholders as the decision making group such as the government in making decision. While the issue in making decision that has social and environmental issue parameters should involve stakeholders to avoid conflicts in decision making.

For the research of [12], it implements the development of computation technique which is able to model and analyze the very complex issue. The purpose of the research implements soft computing concept development in the field of plantation to support natural resource maintenance. 
The five methods applied are FL, FANNs, genetic algorithm, decision tree, and the support from vector machine. The result of the research is to develop decision making in maintaining the effect of environmental effect and natural resource on land and water. The weakness of the research is that it does not explain the process of categorizing the criteria and the assessment process using FANNs, so that it needs a more complete elaboration using FANNs method. The research also emphasize more on the theoretical development so that the implementation of decision making using hybrid method cannot be seen yet.

Meanwhile, the study of the research [8] developed a model of water irrigation resource, so that it needs a decision making method to evaluate the planning of national projects on water maintenance. The method of the research employed FAHP based on the technique of FMCDM with benefit and cost approach, with the parameter based on the economic, social and environmental criteria. The objective of the research is to utilize the planning in maintaining water resource in related projects. The weakness of the research is that it did not involve model stakeholders in completing complex issues. Where the complex issues needs the involvement of stakeholders in making decisions.

The research study [13] implemented hybrid approach in analyzing the problem of land suitability. To analyze the data, the result of the research using fuzzy logic and FANP. The purpose of this study was to perform hybrid to FAHP and AHP method are used to determine the level of various factors of suitability and result in the weight used to develop the suitability of the level in spatial data. The model of the research is also based on GIS to analyze the suitability of the land. For complex issue in this research, it also did not involve multi-stakeholders in making decision, so that it can be developed using multi-stakeholders-based decision.

In the research [14] explains the process of the conversion of the mud wasted soil in plantation field. Model using the mapping and characteristic of spatial data to recognize the field of the land that received mud-waste on the plantation land. Spatial MCDA method uses FAHP which aims to analyze the suitability of land that receives mud waste. Each map input is analyzed to result modelling process showing that the area that suitable and right to receive mud waste. The weakness of the research is in explaining seems to still complete in assessing criteria weighing - the parameter of environmental effect on the land conversion of the mud waste in the plantation. So that a sequence modelling process based on the categorized criteria and the process of criteria assessing in decision making so that it can provide weighing on each model of data spatial. The process of decision making should also involve some stakeholders in determining the effect of mud-waste in the plantation such as farmer, government and any other stakeholders.

While the presentation of the research [15] made a model of decision making to find a plantation land that suits with the area of Turkey. The purpose of the settlement of the problem solving technique in this research is to know the suitability of the plantation land. Therefore, to know the number of plantation production that suits best with the type of the land to be planted. The method is presented using FAHP assessment to assess each land suitability parameter which is considered to be bias, while GIS visualization is used to know the location of the plants. The weakness of the research occurs in the criteria and sub-criteria assessment. Where the criteria is directly burdened by the weight without considering the other aspects. Hence, it needs to develop a model in the assessment of the land for plantation. The development of the model needs the involvement of the stakeholders in providing assessment to each criteria and sub-criteria from all parameter use.

The research [10] results a hybrid model research for decision making using FMCDM using method of FL, ELETRE I, REGIME analysis, FAHP, FOWA, and Dominance based on Rough Set Approach. The purpose of of the research also integrates FMCDM and GIS method so it results a decision making through data spatial output. Based on the characteristic of developed modular model package, Massei's research still enables to add new methods without modifying the existing structure. The weakness of the research is that it does not show the result of the output decision for making decision of land clearing for plantation, so that decision makers know the result of output in determining the land. The research is more to develop a model and integrates it with model fuzzy multi-criteria decision making based on spatial data. Other weakness of the research will only be seen on its comparison to the utilization of FAHP and FOWA in the form of map visualization. It does not show the weighing technique and the finishing process in making decision. In this research 
it also needs weighing by involving multi-stakeholders so that it can help a lot to DMs in making the decision.

The different result of the research [9], it employs the application of decision making to determine the rank of the utilization of the land after the mine that can be used for people's interest. The purpose of the research provides recommendation for the decision of the land after the mine used for plantation. The assessment model matrix using FAHP method and FTOPSIS method. On FAHP is use to obtain important role from the attribute and the method of FTOPSIS to determine the result of alternative rank. According to Masoumi and Naraghi, the model has the benefits in economic, technical, environmental, and social aspect. The model can be used to apply land clearing for plantation such as post-mine land. The weakness of the research is that it did not involve group of stakeholders in determining the criteria weight, so that it can still be developed for group decision making using the method.

Meanwhile the research result of [35] employed assessment to maintain plant industry. The decision making model used is group decision making (GDM) with the assessment method of FTOPSIS and Sensitivity Analysis (SA). Purpose of this study for compare FTOPSIS with TOPSIS MCDM so that the result of the rank for decision making for the stage of maintenance of plantation industry. The research also has weakness in its presentation that it emphasizes more on the comparison of TOSIS and FTOPSIS in completing the issue of plant maintenance, so that it needs to test it with other FMCDM such as FAHP or FELECTRE. The research is also needed to develop with involving many decision makers (DMs), so that the involvement of multi-stakeholder in providing criteria weight in TOPSIS method and FTOPSIS method is more effective.

Meanwhile in the presentation of the research [11] yielded a planning theory encouraging all stakeholders with various discourse in assessing the criteria to avoid decisions that have political and manipulative influences. The model used in Mosadeghi aimed to avoid conflict in social and political area. The model is more suitable for the problems involving stakeholders in the decision making. So that it will help in political transition period for its planning policies to make decision. The method used is by implementing a study comparing the result of two quantitative technique on AHP and FAHP in the planning of determining the urban land in big scale. Therefore, the comparing model for the planning theory in this case might help land clearing issues to find a location that is suitable with the interest of the government, people, and investors. The weakness of the result of the research is that there are only two comparing methods used between AHP and FAHP. Hence, it needs to compare them in other methods such as FTOPSIS or FELECTRE. Other problem regarding the weakness of the research is that the research only sees some criteria aspects in land clearing such as Residential, extractive industry, marine industry, and recreation. There needs also criteria in the aspect of environmental effects, and economic in the future. Therefore, the value of the land is estimated to be more advance or slow in its growth.

The result of categorizing the literature review using FMCDM in land clearing can be seen on Table 1.

Table 1. Literature review based on FMCDM for land clearing for plantation.

\begin{tabular}{|c|c|c|c|c|c|c|}
\hline \multirow{2}{*}{$\begin{array}{l}\text { Publications } \\
\text { (authors, year) }\end{array}$} & \multicolumn{6}{|c|}{ Fuzzy Multi Criteria Decision Making } \\
\hline & $\begin{array}{l}\text { Fuzzy } \\
\text { AHP }\end{array}$ & $\begin{array}{l}\text { Fuzzy } \\
\text { OWA }\end{array}$ & $\begin{array}{c}\text { Fuzzy } \\
\text { ELECTRE }\end{array}$ & $\begin{array}{c}\text { Fuzzy } \\
\text { TOPSIS }\end{array}$ & $\begin{array}{l}\text { Fuzzy } \\
\text { ANNs }\end{array}$ & Other \\
\hline $\begin{array}{l}\text { (H. Chiou 2002) } \\
\text { (S. Baja et al. 2007) } \\
\text { (N. Chang et al. 2008) } \\
\text { (Y. Huang et al. 2010) } \\
\text { (K. P. Anagnostopoulos and C. Petalas. 2010) } \\
\text { (B. Feizizadeh and T. Blaschke, 2012) } \\
\text { (A. Passuello et al. 2012) } \\
\text { (H. Akinci et al. 2013) } \\
\text { Massei et al. 2014) } \\
\text { (I. Masoumi et al. 2014) } \\
\text { (S.hong ding and K. Shahrul 2014) } \\
\text { (R. Mosadeghi et al. 2015) }\end{array}$ & $\begin{array}{l}\sqrt{ } \\
\sqrt{ } \\
\sqrt{ } \\
\sqrt{ } \\
\sqrt{ } \\
\sqrt{ } \\
\sqrt{ }\end{array}$ & $\sqrt{ }$ & $\begin{array}{l}\sqrt{ } \\
\sqrt{ }\end{array}$ & $\begin{array}{l}\sqrt{ } \\
\sqrt{ }\end{array}$ & $\sqrt{ }$ & $\begin{array}{l}\sqrt{ } \\
\sqrt{ } \\
\sqrt{ } \\
\sqrt{ } \\
\sqrt{ } \\
\sqrt{ } \\
\sqrt{ } \\
\sqrt{ } \\
\sqrt{ }\end{array}$ \\
\hline & 10 & 1 & 3 & 2 & 2 & 11 \\
\hline
\end{tabular}




\section{B. Analytical result of FMCDM Model}

The result of literature review done is related to the problems of land clearing and the environmental effect using FMCDM. The land clearing such in the post mining land clearing for plantation and pre land clearing for plantation. The data of the result obtained shows the average percentage using FMCDM model as in the method of FAHP [5]-[11], [14], [15], [47], FOWA [10] , FELECTRE [5], [10], [15], FTOPSIS [9], [35], and FANNs in [12], [13] as well as other methods integrated in FMCDM. The result of the presentation of previous research generally uses more than one method for making decision of land clearing. The percentage result of our analysis for the research using FMCDM on the land clearing problem can be seen in Fig. 1.

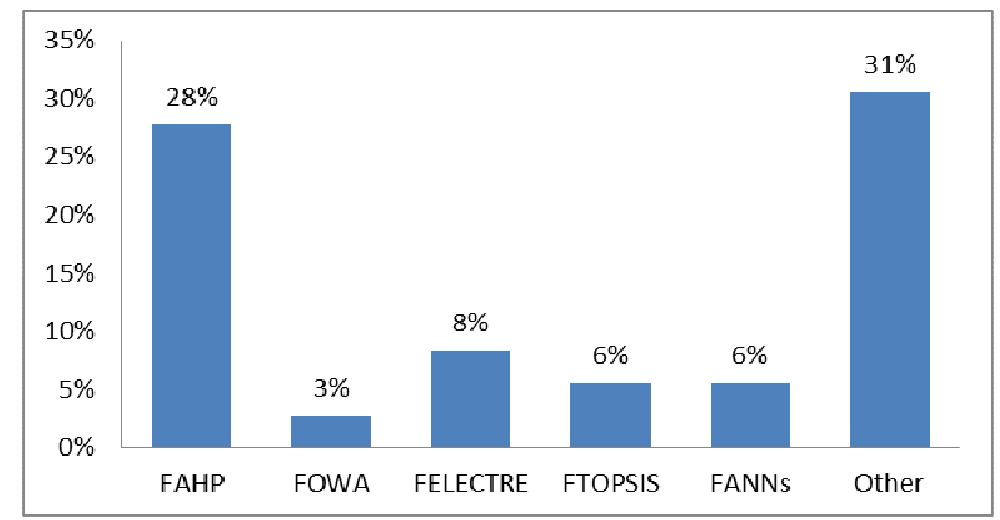

Fig. 1. Percentage of literature review using FMCDM for land clearing

From out analysis, it is known from the number of the paper of the research result surveyed that uses FMCDM model there is method FAHP of 28\%, while method FOWA 3\%, FELECTRE 8\%, FTOPSIS $6 \%$ and FANN 6\%. While some authors also result some researches by implementing hybrid to other method, such as using Fuzzy nonadditive ([5], Fuzzy ANP [10]; [13] and Fuzzy Logic [12], [13], as well as in Fuzzy PIS and Fuzzy NIS in completing FTOPSIS [35] and the rest is $31 \%$. Some research obtained also integrates FMCDM to the method of GIS to visualize the land location. The technique is used to show the real life location display as well as to enable the assessment of the criteria in decision making

\section{Conclusion}

From Table 1, the results of the survey analysis showed a significant percentage of FAHP other methods. This method is widely used in a problem of land clearing using FMCDM. All papers obtained use more than one method in completing land clearing problem. For the method can be used in comparing each criteria and sub-criteria on the method used and other method for decision making. The method has different weight of interest level, so that in completing the problem related to the environmental effect can be accepted by stakeholders in decision making. Some research also shows the research result that integrates FMCDM into GIS to show the location of land clearing. The technique of method combination is very good for the problem of decision making in land clearing so that it is efficient for the output data of map visualization. The research using the method might solve the problem of decision making for land clearing for palm plantation that involves multi-stakeholder which might have different parameter-criteria in the decision making. For the next research, it needs to develop integration model collaborating model FMCDM into multi-spatial data model. The technique of weighting mentioned is involving multi-stakeholder in assessing multicriteria for decision making so that it can develop theory of FMCDM into the theory of Fuzzy MultiSpatial Decision Making (FMSDM). Multi-spatial models are used as input and output geographically for decision making. The use of this model will show the results of the ranking with such multi-map visualization.

\section{References}

[1] C. Carlsson and R. Fullér, "Fuzzy multiple criteria decision making: Recent developments," Fuzzy Sets Syst., vol. 78, no. 2, pp. 139-153, Mar. 1996. 
[2] C. Kahraman, "Fuzzy Multi-Criteria Decision Making,” vol. 16, pp. 1-18, 2008.

[3] F. T. S. Chan, H. K. Chan, and A. Kazerooni, "A Fuzzy Multi-Criteria Decision-Making Technique for Evaluation of Scheduling Rules,” pp. 103-113, 2002.

[4] L. Abdullah, "Fuzzy Multi Criteria Decision Making and its Applications: A Brief Review of Category," Procedia - Soc. Behav. Sci., vol. 97, pp. 131-136, Nov. 2013.

[5] H. Chiou, "Fuzzy Multiple-Criteria Decision-Making Approach for Industrial Green Engineering," vol. 30, no. 6, pp. 816-830, 2002.

[6] S. Baja, D. M. Chapman, and D. Dragovich, "Spatial based compromise programming for multiple criteria decision making in land use planning," pp. 171-184, 2007.

[7] N. Chang, G. Parvathinathan, and J. B. Breeden, "Combining GIS with fuzzy multicriteria decisionmaking for landfill siting in a fast-growing urban region," vol. 87, pp. 139-153, 2008.

[8] K. P. Anagnostopoulos and C. Petalas, "A fuzzy multicriteria benefit-cost approach for irrigation projects evaluation," Agric. Water Manag., vol. 98, no. 9, pp. 1409-1416, Jul. 2011.

[9] I. Masoumi and S. Naraghi, "Application of fuzzy multi-attribute decision-making to select and to rank the post-mining land-use," pp. 221-231, 2014.

[10] G. Massei, L. Rocchi, L. Paolotti, S. Greco, and A. Boggia, "Decision Support Systems for environmental management: A case study on wastewater from agriculture," J. Environ. Manage., vol. 146, pp. 491-504, 2014.

[11] R. Mosadeghi, J. Warnken, R. Tomlinson, and H. Mirfenderesk, "Computers , Environment and Urban Systems Comparison of Fuzzy-AHP and AHP in a spatial multi-criteria decision making model for urban land-use planning," Comput. Environ. Urban Syst., vol. 49, pp. 54-65, 2015.

[12] Y. Huang, Y. Lan, S. J. Thomson, A. Fang, W. C. Hoffmann, and R. E. Lacey, "Development of soft computing and applications in agricultural and biological engineering," Comput. Electron. Agric., vol. 71, no. 2, pp. 107-127, 2010.

[13] B. Feizizadeh and T. Blaschke, "Land suitability analysis for Tabriz County." pp. 1-12, 2012.

[14] A. Passuello, O. Cadiach, Y. Perez, and M. Schuhmacher, "A spatial multicriteria decision making tool to de fi ne the best agricultural areas for sewage sludge amendment," Environ. Int., vol. 38, no. 1, pp. 19, 2012.

[15] H. Akınc1, A. Y. Özalp, and B. Turgut, “Agricultural land use suitability analysis using GIS and AHP technique," Comput. Electron. Agric., vol. 97, pp. 71-82, Sep. 2013.

[16] M. N. A. Khalid and U. K. Yusof, "A knowledge-based expert system for the smallholder palm oil cultivator in Malaysia,” IEEE Student Conf. Res. Dev., pp. 256-261, Dec. 2012.

[17] M. R. Sarmidi, H. A. El Enshasy, M. A. Hamid, N. Burg, and A. Arab, "Oil Palm: The Rich Mine for Pharma, Food, Feed and Fuel Industries Chemical Engineering Pilot Plant ( CEPP ), Faculty of Chemical and Natural Resource Engineering, Department of Bioprocess Development, GEBRI , Mubarak City for Scientific Research ," Am. J. Agric Environ. Sci, vol. 5, no. 6, pp. 767-776, 2009.

[18] J. R. a. Butler, G. Y. Wong, D. J. Metcalfe, M. Honzák, P. L. Pert, N. Rao, M. E. van Grieken, T. Lawson, C. Bruce, F. J. Kroon, and J. E. Brodie, "An analysis of trade-offs between multiple ecosystem services and stakeholders linked to land use and water quality management in the Great Barrier Reef, Australia,” Agric. Ecosyst. Environ., vol. 180, pp. 176-191, Nov. 2013.

[19] J. M. Gonçalves, L. S. Pereira, S. X. Fang, and B. Dong, "Modelling and multicriteria analysis of water saving scenarios for an irrigation district in the upper Yellow River Basin," Agric. Water Manag., vol. 94, no. 1-3, pp. 93-108, Dec. 2007.

[20] F. Akande, K. Oriola, O. Oniya, and G. Bolaji, "Level of Oil Palm Production Mechanization in Selected Local Government Areas of Oyo and Osun States , Nigeria .," Innov. Syst. Des. Enginneering, vol. 4, no. 9, pp. 36-40, 2013.

[21] Suwondo, "Efek Pembukaan Lahan terhadap Karakteristik Biofisik Gambut pada Perkebunan Kelapa Sawit di Kabupaten Bengkalis," J. Natur Indones., vol. 14, no. 2, pp. 143-149, 2012.

[22] USDA, "United States Department of Agriculture:. ' global palm oil consumption of global palm oil production' . URL: http://www.usda.gov," 2012.

[23] K.-O. Wenkel, M. Berg, W. Mirschel, R. Wieland, C. Nendel, and B. Köstner, "LandCaRe DSS--an interactive decision support system for climate change impact assessment and the analysis of potential agricultural land use adaptation strategies.," J. Environ. Manage., vol. 127 Suppl, pp. S168-83, Sep. 2013. 
[24] R. Elsheikh, A. R. B. Mohamed Shariff, F. Amiri, N. B. Ahmad, S. K. Balasundram, and M. A. M. Soom, "Agriculture Land Suitability Evaluator (ALSE): A decision and planning support tool for tropical and subtropical crops," Comput. Electron. Agric., vol. 93, pp. 98-110, Apr. 2013.

[25] W. F. A. El-wahed, "Intellligent fuzzy multi-criteria decision making : Review and analysis," vol. 1, no. 1, pp. 19-51, 2008.

[26] R. R. Yager, "Uncertainty modeling and decision support," Reliab. Eng. Syst. Saf., vol. 85, no. 1-3, pp. 341-354, Jul. 2004.

[27] R. W. Saaty, "The analytic hierarchy process-what it is and how it is used," Math. Model., vol. 9, no. 35, pp. 161-176, 1987.

[28] S.M.Tofighy, R.G. Raj, and H.H.S. Javadi, “AHP Techniques for Persian Text Summarization. pp 1-8," Malaysian J. Comput. Sci., vol. 26, no. 1, pp. 1-8, 2013.

[29] T. L. Saaty, K. Peniwati, and J. S. Shang, "The analytic hierarchy process and human resource allocation: Half the story," Math. Comput. Model., vol. 46, no. 7-8, pp. 1041-1053, Oct. 2007.

[30] T.L. Saaty and I. Basak, "Group Decision Making Using The Analytic Hierarchy Process," Math. Comput. Model., vol. 17, no. 4-5, pp. 101-109, 1993.

[31] R. R. Yager, "Multiple objective decision - making using fuzzy sets," Int. J. Man. Mach. Stud., vol. 9, no. 4, p. 1977, 1977.

[32] R. R. Yager, "Lexicographic ordinal OWA aggregation of multiple criteria," Inf. Fusion, vol. 11, no. 4, pp. 374-380, Oct. 2010.

[33] C. L. Hwang and K. Yoon, Multiple Attribute Decision Making: Methods and Applications. New York: Springer-Verlag, 1981.

[34] D. L. Olson, “Comparison of Weights in TOPSIS Models,” vol. 40, pp. 721-727, 2004.

[35] S. h. Ding and K. Shahrul, "Assessment of distance-based multi-attribute group decision- making methods from a maintenance strategy perspective," J Ind Eng Int, vol. 10, no. 78, pp. 1-13, 2014.

[36] A. Hatami-Marbini and M. Tavana, "An extension of the Electre I method for group decision-making under a fuzzy environment," Omega, vol. 39, no. 4, pp. 373-386, Aug. 2011.

[37] B. Roy, “The outrangking foundations approach and the methode," pp. 49-73, 1991.

[38] M.-C. Wu and T.-Y. Chen, "The ELECTRE multicriteria analysis approach based on Atanassov's intuitionistic fuzzy sets,” Expert Syst. Appl., vol. 38, no. 10, pp. 12318-12327, Sep. 2011.

[39] L. Botti and N. Peypoch, "Multi-criteria ELECTRE method and destination competitiveness," Tour. Manag. Perspect., vol. 6, pp. 108-113, Apr. 2013.

[40] D. Golmohammadi, "Neural network application for fuzzy multi-criteria decision making problems," Int. J. Prod. Econ., vol. 131, no. 2, pp. 490-504, Jun. 2011.

[41] S. a. Kalogirou, G. a. Florides, P. D. Pouloupatis, P. Christodoulides, and J. Joseph-Stylianou, "Artificial neural networks for the generation of a conductivity map of the ground," Renew. Energy, vol. 77, pp. 400-407, May 2015.

[42] G. Özkan and M. İnal, "Comparison of neural network application for fuzzy and ANFIS approaches for multi-criteria decision making problems," Appl. Soft Comput., vol. 24, pp. 232-238, Nov. 2014.

[43] I. Pahan, "Complete Guide Palm Oil (Agribusiness Management from Upstream to Downstream)," Swadaya Publ. Jakarta, 2013.

[44] M. Pandamean, "Succesful Plantation and Mills," Swadaya Publ. Jakarta, 2015.

[45] N. van Vliet, O. Mertz, A. Heinimann, T. Langanke, U. Pascual, B. Schmook, C. Adams, D. SchmidtVogt, P. Messerli, S. Leisz, J.-C. Castella, L. Jørgensen, T. Birch-Thomsen, C. Hett, T. Bech-Bruun, A. Ickowitz, K. C. Vu, K. Yasuyuki, J. Fox, C. Padoch, W. Dressler, and A. D. Ziegler, "Trends, drivers and impacts of changes in swidden cultivation in tropical forest-agriculture frontiers: A global assessment," Glob. Environ. Chang., vol. 22, no. 2, pp. 418-429, May 2012.

[46] B. H. Simanjuntak, "Study of forest land use change to farming land use towards soil physical characteristic (case study of kali tundo wathershed, Malang)," AGRIC, vol. 18, no. 1, pp. 85-101, 2005.

[47] B. Feizizadeh, "Journal of Environmental Planning and Land suitability analysis for Tabriz County , Iran : a multi-criteria evaluation approach using GIS," no. April 2012, pp. 37-41.

[48] W. Zgłobicki, B. Baran-Zgłobicka, L. Gawrysiak, and M. Telecka, "The impact of permanent gullies on present-day land use and agriculture in loess areas (E. Poland)," Catena, vol. 126, pp. 28-36, Mar. 2015. 
[49] R. Babigumira, A. Angelsen, M. Buis, S. Bauch, T. Sunderland, and S. Wunder, "Forest Clearing in Rural Livelihoods: Household-Level Global-Comparative Evidence," World Dev., vol. 64, pp. S67S79, Dec. 2014.

[50] G. Muriuki, L. Seabrook, C. McAlpine, C. Jacobson, B. Price, and G. Baxter, "Land cover change under unplanned human settlements: A study of the Chyulu Hills squatters, Kenya," Landsc. Urban Plan., vol. 99, no. 2, pp. 154-165, Feb. 2011.

[51] T. Mattila, J. Seppälä, A. Nissinen, and I. Mäenpää, "Land use impacts of industries and products in the Finnish economy: A comparison of three indicators," Biomass and Bioenergy, vol. 35, no. 12, pp. 4781-4787, Dec. 2011.

[52] G. De Feo and S. De Gisi, "Using MCDA and GIS for hazardous waste landfill siting considering land scarcity for waste disposal.," Waste Manag., vol. 34, no. 11, pp. 2225-38, Nov. 2014.

[53] O. a Ehigiator and B. U. Anyata, "Effects of land clearing techniques and tillage systems on runoff and soil erosion in a tropical rain forest in Nigeria.," J. Environ. Manage., vol. 92, no. 11, pp. 2875-80, Nov. 2011. 